Multidisciplinary

SCIENTIFIC JOURNAL OF

MARITIME RESEARCH

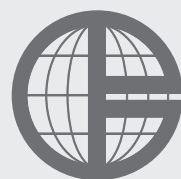

University of Rijeka

Faculty of Maritime

Studies Rijeka
Multidisciplinarni

znanstveni časopis

POMORSTVO

https://doi.org/10.31217/p.32.2.16

\title{
Organisational structure and analysis of the contribution of the Coast Guard of the Republic of Croatia to maritime safety on the Adriatic Sea
}

\author{
Tomislav Sunko ${ }^{1}$, Pavao Komadina ${ }^{2}$, Luka Mihanović ${ }^{1}$ \\ ${ }^{1}$ Croatian Military Academy “Dr Franjo Tuđman”, 10000 Zagreb, Croatia, e-mail: tomosunko@gmail.com; mlmihanovic@gmail.com \\ ${ }^{2}$ University of Rijeka, Faculty of Maritime Studies, Studentska 2, 51000 Rijeka, Croatia, e-mail: komadina@pfri.hr
}

\begin{abstract}
This paper analyses the organisation and scope of activities of the Coast Guard of the Republic of Croatia. The Coast Guard of the Republic of Croatia is a military organisation with police authorities and is an integral part of the Croatian Navy. It is a task force whose basic purpose is to provide support to state administration bodies in charge of surveillance and protection of Croatian strategic, economic and other general national interests on the eastern side of the Adriatic Sea. It is necessary to stress that the Croatian Coast Guard is trained not only to carry out protection of national maritime interests but also to carry out combat tasks and to participate in joint operations in the national and international environment. This paper contributes in stressing the importance of the role of the Croatian Coast Guard and of investments in equipment and in human resource with the aim of maintaining maritime safety on the Adriatic Sea.
\end{abstract}

\section{ARTICLE INFO}

Rewiew article

Received 25 October 2018

Accepted 18 December 2018

Key words:

Coast Guard

Republic of Croatia

Croatian Navy

Adriatic Sea

\section{Introduction}

One of most important items in the Gross Domestic Product is tourism [13]. On account of its indented coastline and islands and ecologically clean marine environment, the Republic of Croatia (RC) has become a top tourist destination. As a result, the economic development and strategic orientation of the RC is closely connected to the development of the eastern side of the Adriatic Sea. Bearing in mind uncertainty of long-term challenges of the security environment due to its geostrategic position along the eastern Adriatic coast (new, non-traditional, sophisticated, asymmetric threats - sudden, unexpected, temporal or spatial attacks), migrant/refugee crisis, increased maritime traffic (possibilities of unexpected pollution, ballast water), protection of all the interests of the RC implies an obligation to increase all supervising activities in the waters of the eastern Adriatic.

In order to successfully protect and preserve national interests of the RC, it was essential to introduce an additional concept of the maritime protection through joint activities of port authorities, maritime police, Croatian Navy (CN), customs administration, search and rescue services, bodies in charge of intervention of measures in case of marine pollution and marine fisheries inspectors, so as to, by applying additional support, enhance efficiency of all the members in increasing the security in the maritime area of the RC.

If we add to this the future implementation of the Schengen Agreement [17], it is clear that the task of protecting maritime interests of the $\mathrm{RC}$ transcends into the protection of European Union interests as well. The establishment of the Coast Guard of the Republic of Croatia (CGRC) constituted this additional support to more efficient and quicker mutual interaction of all maritime, state, and civilian services in the implementation of surveillance and protection of Croatian interests in line with international rules and regulations.

By the Decision of the Croatian Parliament of October 2003, the Ecological and Fishery Protection Zone (EFPZ) was promulgated [2]. On the day the Decision on the promulgation of the EFPZ entered into force the Central Coordinating Committee for Supervision and Protection of the Maritime Rights and Interests of the Republic of Croatia was set up. In order to prevent overlapping of authorities of certain state administration bodies (SAB) 
and achieve more rational use of funds, the Government of the Republic of Croatia set up the Coordinating Committee of the Government of the Republic of Croatia for Harmonisation of the Supervision and Protection of the Inland Waters, Territorial Waters, and the Protected Ecological-Fishing Zone ${ }^{1}$ [1].

The subject of the research is the implementation of supervision and protection of Croatian national interests on the eastern side of the Adriatic.

The object itself of this research derives from the preoccupation and subject matter of the research, which is the organisational structure and activities of the CGRC.

The object itself of this research derives from the preoccupation and subject matter of the research, which is the organisational structure and scope of activities of the CGRC.

In line with basic guidelines of the preoccupation, subject matter and object of the research, a working hypothesis has been formulated which says: After finding out about new security threats on the eastern Adriatic, it is of utmost importance for the CGRC to continue with modernisation of its own maritime and attached air forces, to continue with relocation of a part of its naval forces, and to continue with expert training of its human resources, being its most important force.

The purpose and aim of this research are reflected in the following: in order to increase and efficiently carry out the implementation of monitoring and protecting of interests of the RC in the Adriatic Sea in all directions required by security issues, it is necessary to modernise naval and air forces of the CGRC and to continue with professional training of human resource of the CGRC.

\section{The Coast Guard of the Republic of Croatia}

The total of the territory under the sovereignty of the Republic of Croatia (inland waters and territorial sea) amounts to $31,757.67 \mathrm{~km}^{2}$, whereas on a great part of the Adriatic Sea, outside of the state territory, the RC exercises certain sovereign rights and jurisdiction (the area over which the RC exercises certain sovereign rights and jurisdiction amounts to $25,207.22 \mathrm{~km}^{2}$ and the area of the external borders of the EFPZ amounts to $23,870 \mathrm{~km}^{2}$ ). The total jurisdiction area currently amounts to $56,964.89 \mathrm{~km}^{2}$. It is of great importance to supervise this very important economic resource of the RC in an organised and effective way [6].

In Zagreb on $3^{\text {rd }}$ October 2007, the Croatian Parliament passed the Act on the Coast Guard of the Republic of Croatia (ACGRC) which determines the organisation and scope of activities of the CGRC, its authority, jobs and tasks it will be authorised to carry out. The ACGRC entered into force on $1^{\text {st }}$ November 2007. Provisions of the Act on Service in the Armed Forces shall be applied on members of the CGRC in relation to issues not covered by the ACGRC [4].

\footnotetext{
1 Amendments to the Decision prescribe that the EFPZ of the Republic of Croatia shall temporarily not apply to the EU Member States.[3].
}

Organising of the CGRC changed the structure of the CN as well. According to the new structure the $\mathrm{CN}$ consists of the Headquarters, Flotilla, Coast Guard of the Republic of Croatia, Coast Surveillance and Warning Battalion, Maritime Base, Training Centre and Navy Command Club [21].

The CGRC is the main force in the protection of interests over the part of the sea, sea bed and underground where the RC exercises its sovereign rights. The CGRC can provide assistance in the maritime area of the Republic of Croatia if it is considered necessary [5].

In this way, the CGRC has become an integral part of the Central Coordinating Committee for Supervision and Protection of the Maritime Rights and Interests of the Republic of Croatia. The Central Coordinating Committee monitors and analyses the state of security and protection of the maritime area under the jurisdiction of the RC, gives guidelines for drawing up of plans dealing with the surveillance and protection of maritime rights of the RC, submits annual reports to the Government of the RC on the implementation of determined policies, plans, regulations related to the surveillance and protection of maritime interests of the $\mathrm{RC}$, and recommends measures intended to improve security and protection of the maritime area under the Croatian jurisdiction. The Central Coordinating Committee is composed of an Expert Body (16 members from different government departments) and of regional coordination units. It is necessary to emphasise that the chairman of the Expert Body is a commander of the CGRC and that the Headquarters of the CGRC performs administrative tasks for the Expert Body [4].

In the EFPZ, epicontinental sea and open sea, the CGRC protects sovereign rights and takes care of the implementation of the jurisdiction of the RC, whereas in the area of inland waters and territorial sea it provides support to other authorised state administration bodies in the implementation of acts and other regulations within their jurisdiction and in line with the ACGRC [5].

According to the ACGRC, basic activities and tasks of the CGRC are protection of the state sovereignty, its sovereign rights and jurisdiction at sea. In addition to the mentioned ones, its basic tasks also include suppression and prevention of terrorism, international organised crime (illegal trafficking of weapons and narcotic drugs, prevention of trafficking of goods and people, illegal migrations), sea robberies (suppression of piracy and other types of usage of the open sea for contentious purposes), spreading of mass destruction weapons, suppression, reduction and supervision of pollution of the sea and marine environment, search and rescue at sea, securing of adequate navigation regime (navigation safety), control of sea fishery, protection of sensitive ecosystems, habitats and other endangered forms of life in the sea, protection of underwater cultural goods in the EFPZ, epicontinental sea and open sea of the Republic of Croatia [4].

Since $13^{\text {th }}$ March the EFPZ has temporarily not been applying to EU Member States, until a common agreement in the EU spirit has been found [9]. 
When the CGRC was organised, its foundation were human resources at the disposal of the $\mathrm{CN}$ and available task force vessels. At this moment, considering existing and future threats and complexity of CGRC tasks, it is essential to ensure every further technological advancement by providing financial and logistic support to equipping of CGRC. Every new investment in equipment, modernisation and personnel is necessary in order to develop and achieve capabilities of the CGRC for its support to other state and civilian structures in the implementation of RC interests throughout the Adriatic Sea [6].

Funds for financing of planning, equipping and modernising of task force vessels and aircraft, operational expenses of CGRC human resources will be ensured through the state budget of the RC (Article 41 of the ACGRC) or through EU funds [4].

In case of a war or an immediate war threat, CGRC forces will act as an operational component of the Armed Forces of the Republic of Croatia (CAF) organised and prepared for carrying out of combat and non-combat operations as a part of naval forces, so as to fulfil its constitutional role to protect against aggression [21].

\subsection{Organisational structure and scope of activities carried out by the Coast Guard of the Republic of Croatia}

The structure of the CGRC is passed by the President of the Republic of Croatia at the proposal of the Government of the Republic of Croatia. The commander of the CGRC is a CN officer who is appointed and relieved of duty by the President of the Republic of Croatia at the proposal of the Government of the Republic of Croatia [4].

The CGRC is an autonomous vessel unit whose headquarters and first division are stationed in the barracks "Admiral flote Sveto Letica-Barba" in Split [4], and naval forces of the second division are operationally stationed in Pula.

\subsection{Headquarters of the Coast Guard of the Republic of Croatia}

The Headquarters of the Coast Guard is an expert body of the Coast Guard commander. The Headquarters is authorised to plan and execute tasks, conduct coordination of the CGRC with other entities in charge of surveillance and protection of maritime interests of the $\mathrm{RC}$, in line with the ACGRC. The CGRC Headquarters is composed of a personal group, administrative subsection and command of the first and second division. Support and operations departments form the support and execution parts of the CGRC Headquarters together with a group of commanders as a counselling body [4], [1].

Activities carried out by the support part are personnel, administration and logistic affairs, whereas activities carried out by the operations part are planning and coordination affairs [12].

\subsection{First division of the Coast Guard of the Republic of Croatia}

CGRC activities will be carried out by its operational naval forces, and these forces are divided into the first and second division of the CGRC. The first division of the CGRC is operationally and logistically stationed in the barracks "Admiral flote Sveto Letica- Barba" in Split. In the first division we have the following ships:

- school ship class Moma BŠ-72 Andrija Mohorovičić,

- search and rescue ship class Spasilac BS-73 Faust Vrančić,

- patrol boat class Mirna OB-1 Novigrad,

- patrol boat class Mirna OB-2 Šolta,

- water carrier PT-71,

- port tug boat LR-71 [8].

\subsection{Second division of the Coast Guard of the Republic of Croatia}

In 2014, an operational relocation of the second division from the barracks "Admiral flote Sveto Letica- Barba" in Split to the barracks "Varagola" in Pula was carried out, which resulted in the enhancement of capabilities of the CGRC to carry out its basic tasks, with the aim of covering areas of interest of the RC in the Adriatic Sea.

In the second division we have the following ships:

- patrol boat class Mirna OB-3 Cavtat,

- patrol boat class Mirna OB-4 Hrvatska Kostajnica,

- port tug boat LR-73 [11].

The permanent stationing of the CGRC vessels in the port of Pula showed to be efficient for the supervision of waters of the northern Adriatic. In addition to quick reactions and cutting down expenses, it also increased safety of the area of gas platforms, which, as immovable objects, require special protective measures. Tracking of navigation and work of foreign scientific-research vessels in the area under the maritime jurisdiction of the RC was also improved. In this way, functional capabilities of the CGRC were optimised [7].

\subsection{Air forces of the Coast Guard of the Republic of Croatia}

The $93^{\text {rd }}$ Air Force Base of the Croatian Air Force (CAIRF) is a CAIRF unit stationed in the barracks Zemunik with a dislocated squadron of transport helicopters in the barracks "Knez Trpimir" in Divulje near Split.

The CAIRF is a bearer and organiser of the Croatian air defence, develops capabilities of surveillance and protection of the air space of the RC and provides support to ground and naval forces in joint operations. The CAIRF forces are operationally subordinated to the commander of the CGRC. A part which is operationally assigned to the CGRC is composed of:

- two Pilatus PC 9 aeroplanes and

- four Mi-8 MTV 1 helicopters [15]. 


\subsection{Operations duty officer of the Coast Guard of the Republic of Croatia}

An operations duty officer of the CGRC (ODOCGRC) performs an operations duty service in the operations centre of the CN (OCNV).

A task of ODOCGRC is to perform a 24-hour duty during which a maritime surface situation picture is constantly monitored. Coordination of activities and exchange of information between the CG RC and other state administration bodies responsible for surveillance and protection of maritime interests of the RC provide support to operational entities and their vessels in the implementation of the surveillance and protection of maritime interests of the RC [12].

The surveillance of maritime surface situation is carried out by tracking maritime systems in the OCNV through SEVID system which receives data on ships' navigation through the Automatic Identification System (AIS), through the system of radar and visual surveillance, Coast Surveillance and Warning Battalion (CSWB), through the vessel monitoring system (VMS) and through the vessel traffic service (VTS)

The CSWB performs 24-hour surveillance of the eastern side of the Adriatic coast with devices for radar and visual surveillance, GEM 2059 XS radar system (the radar system from 1994, primarily intended for ship navigation) and Enhanced Peregrine radar system, ex Falcon (part of the CN network called "More" composed of four radar stations on the islands of Mljet, Lastovo, Vis and Dugi Otok). All the collected information is, via OCCN, forwarded through communication infrastructure to other interested external users.

The surveillance of the air space is carried out by the air surveillance and navigation (ASAN) battalion, an operationally attached unit of the CAIRF. The ASAN performs 24-hour surveillance of the air space in a defined area of responsibility with FPS 117 radar system.

The ASAN has five stations out of which two are responsible for surveillance of the air space above the Adriatic Sea and they are located on the peninsula of Pelješac (ROTA) and on the mountain of Učka (UČKA), from where they collect, process and forward data to the OCCN. The ODOCGRC, through official communication infrastructure, exchanges data with the National Maritime Centre for Data Collection with its headquarters in Zadar,
Maritime Rescue Coordination Centre (MRCC) in Rijeka, operations centre of the $93^{\text {rd }}$ Air Force Base Zemunik of the CAIRF, VTS, and the central state support body responsible for fishery affairs (Ministry of Agriculture). Representatives of the Ministry of Agriculture are marine fisheries inspectors.

Every day at 0600 and 1600 , the ODOCGRC sends a daily operations report (DOR) to the duty officer of the CGRC. The ODOCGRC receives a report from naval (ships) and attached air forces (aeroplanes and helicopters) of the CGRC only in case of an engagement thereof at time of his operations duty. At 0600 the CGRC duty officer forwards the DOR to the CGRC commander and at 1600 to the operations duty officer at the OCCN.

In case of an emergency in a maritime area under the surveillance and a demand for urgent engagement of naval or atached air forces of the CGRC, the ODOCGRC shall inform the CGRC commander about the new situation and request his approval for their engagement. In case of the CGRC commander's approval, the ODOCGRC, through official communication channels, informs the ship's commander or the operations duty officer in Zemunik barracks or the one in "Knez Trpimir barracks in Divulje.

\section{Conducted activities of the Coast Guard of the Republic of Croatia}

In the analysed period of time for 2015, CGRC forces tasked to carry out surveillance and protection of maritime interests of the RC achieved as follows: [18].

In the analysed period of time for 2016, CGRC forces tasked to carry out surveillance and protection of maritime interests of the RC achieved as follows: [19].

The annual reports for 2015 and 2016 were accepted at the $16^{\text {th }}$ session of the Central Coordinating Committee for Supervision and Protection of the Maritime Rights and Interests of the RC which was held on 20 July 2017, since the Central Coordinating Committee for Supervision and Protection of the Maritime Rights and Interests of the RC did not hold a session in 2016 [7].

In the analysed period of time for 2017, CGRC forces tasked, in joint activities with other SABs, to carry out surveillance and protection of maritime interests of the RC achieved as follows: [20].

Table 1 Completed activities of the CGRC in protection of maritime interests of the RC in 2015

\begin{tabular}{|c|c|c|c|c|}
\hline \multirow{4}{*}{2015} & Planned Tasks & Extraordinary Tasks & Total Of Completed Tasks \\
\cline { 2 - 5 } & Number of Tasks & 109 & 17 & 126 \\
\cline { 2 - 5 } & Sailed nautical miles [NM] & $4,782.20$ & 559.30 & $5,341.50$ \\
\cline { 2 - 5 } & Consumed motor fuel [1] & $179,616.00$ & $25,430.00$ & $205,046.00$ \\
\cline { 2 - 5 } & Flights & 36 & 18 & 54 \\
\hline
\end{tabular}

Source: Republic of Croatia, Central Coordinating Committee for Supervision and Protection of the Maritime Rights and Interests of the RC.: Annual report on the implementation of determined polices, plans and regulations in relation to supervision and protection of the maritime rights and interests of the Republic of Croatia for the year 2015., 2016. 
Table 2 Completed activities of the CGRC in protection of maritime interests of the RC in 2016

\begin{tabular}{|c|c|c|c|c|}
\hline \multirow{4}{*}{2016} & Planned Tasks & Extraordinary Tasks & Total Of Completed Tasks \\
\cline { 2 - 5 } & Number of Tasks & 115 & 28 & 143 \\
\cline { 2 - 5 } & Sailed nautical miles [NM] & $4,612.20$ & $1,222.70$ & $5,834.90$ \\
\cline { 2 - 5 } & Consumed motor fuel [1] & $147,172.50$ & $39,745.00$ & $186,917.50$ \\
\cline { 2 - 5 } & Flights & 46 & 11 & 57 \\
\hline
\end{tabular}

Source: Republic of Croatia, Central Coordinating Committee for Supervision and Protection of the Maritime Rights and Interests of the RC.: Annual report on the implementation of determined police, plans and regulations in relation to supervision and protection of the maritime rights and interests of the Republic of Croatia for the year 2016., 2017.

Table 3 Completed activities of the CGRC in protection of maritime interests of the RC in 2017

\begin{tabular}{|c|c|c|c|c|}
\hline \multirow{4}{*}{2017} & Planned Tasks & Extraordinary Tasks & Total Of Completed Tasks \\
\cline { 2 - 5 } & Number of Tasks & 110 & 14 & 124 \\
\cline { 2 - 5 } & Sailed nautical miles [NM] & $3,890.50$ & $1,090.60$ & $4,981.10$ \\
\cline { 2 - 5 } & Consumed motor fuel [1] & $116,016.98$ & $38,750.00$ & $154,766.98$ \\
\cline { 2 - 5 } & Flights & 45 & 64 & 109 \\
\hline
\end{tabular}

Source: Republic of Croatia, Central Coordinating Committee for Supervision and Protection of the Maritime Rights and Interests of the RC.: Annual report on the implementation of determined polices, plans and regulations in relation to supervision and protection of the maritime rights and interests of the Republic of Croatia for the year 2017., 2018.

In line with demands from the MRCC in Rijeka, in 2017 CGRC air forces responded to the total of ten notifications of pollution of the sea out of which three notifications were within the framework of planned surveillance of the sea. In eight cases these were satellite notifications by the European Maritime Safety Agency EMSA) whereas two notifications were by the Italian Maritime Rescue Coordination Centre (IMRCC) in Rome [10]. Furthermore, 78 supervisions of navigation safety zones around energy resources (gas platforms) in the northern Adriatic Sea were carried out as well as 111 controls of ship navigation as a part of marine fishery control. CGRC ships carried out the identification of 250 fishing boats, whereas 10,053 fishing vessels were registered through a duty service of the ODOCGRC while performing fishing activities in the EFPZ of the RC.
In cooperation with the Ministry of Agriculture, 23 targeted actions of tuna fishing monitoring were carried out, in which EU fisheries inspectors took part along with employees of the Ministry of Agriculture. 17 ships were followed as a part of the supervision of navigation of foreign war ships in the territorial sea of the RC As a part of the navigation supervision task, a total of nine controls of foreign public and scientific research ships, one tourist ship (ship with a mini-submarine) and one international sailing regatta were carried out [10].

Figure one shows a comparison of tasks, both planned and extraordinary ones, completed by the CGRC from 2015 to 2017, within the framework of the Central Coordinating Committee for Supervision and Protection of the Maritime Rights and Interests of the RC.

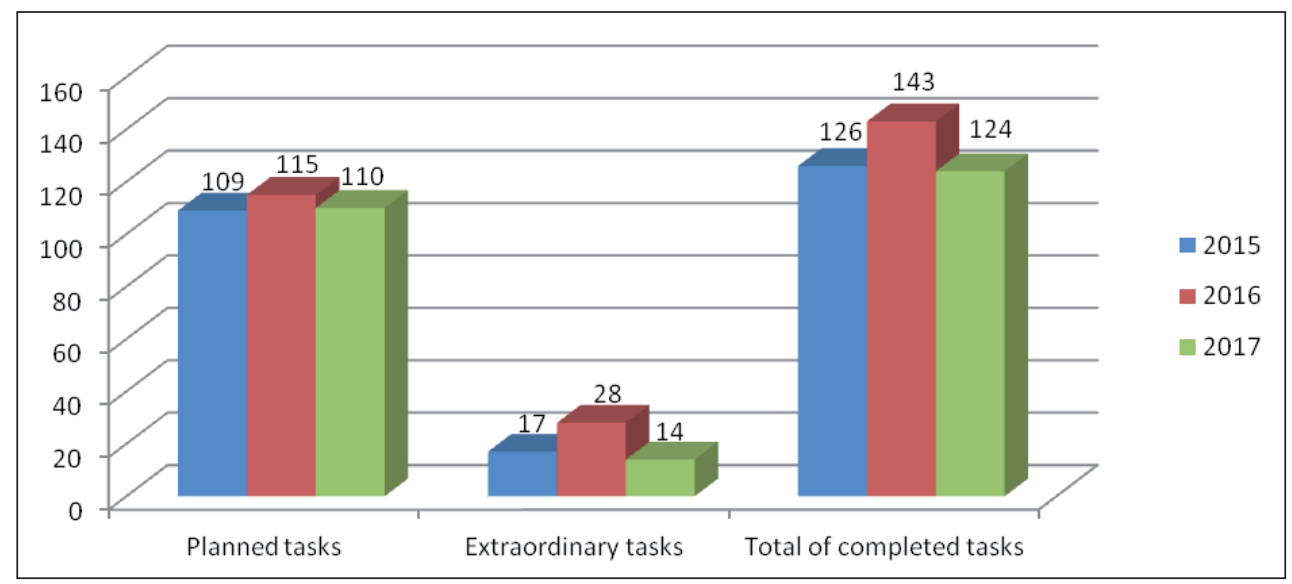

Figure 1 Comparison of completed activities in the period of time from 2015 to 2017 Source: Author, adapted from $[18,19,20]$ 


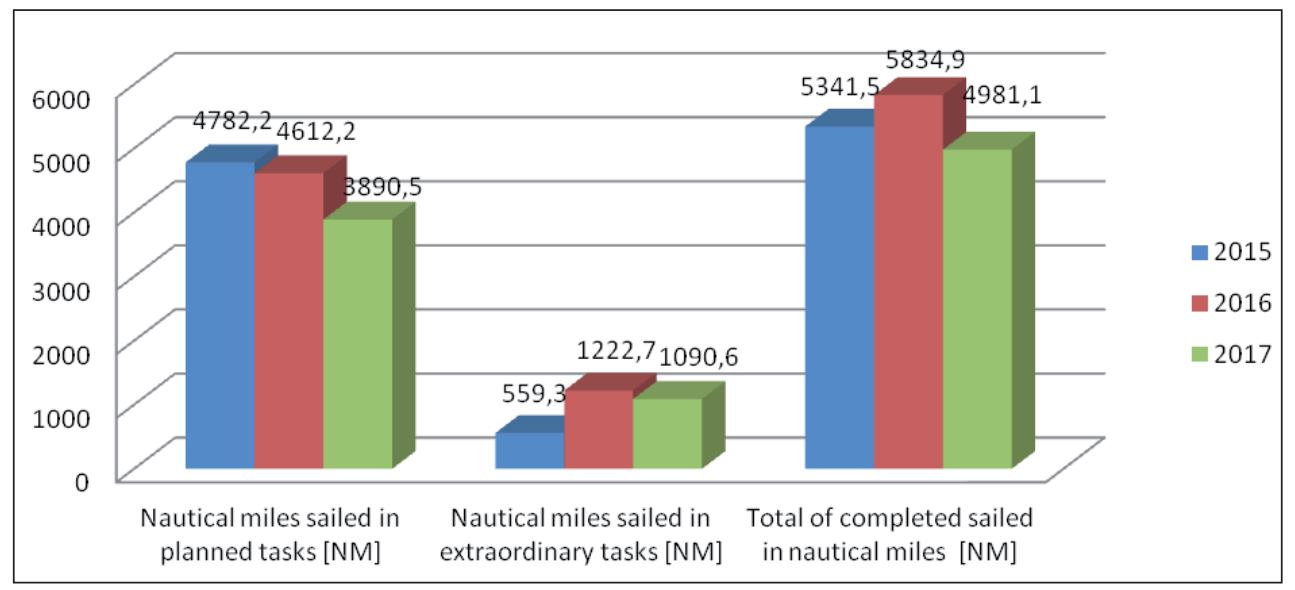

Figure 2 Comparison of nautical miles sailed in the period of time from 2015 to 2017 Source: Author, adapted from [18,19,20]

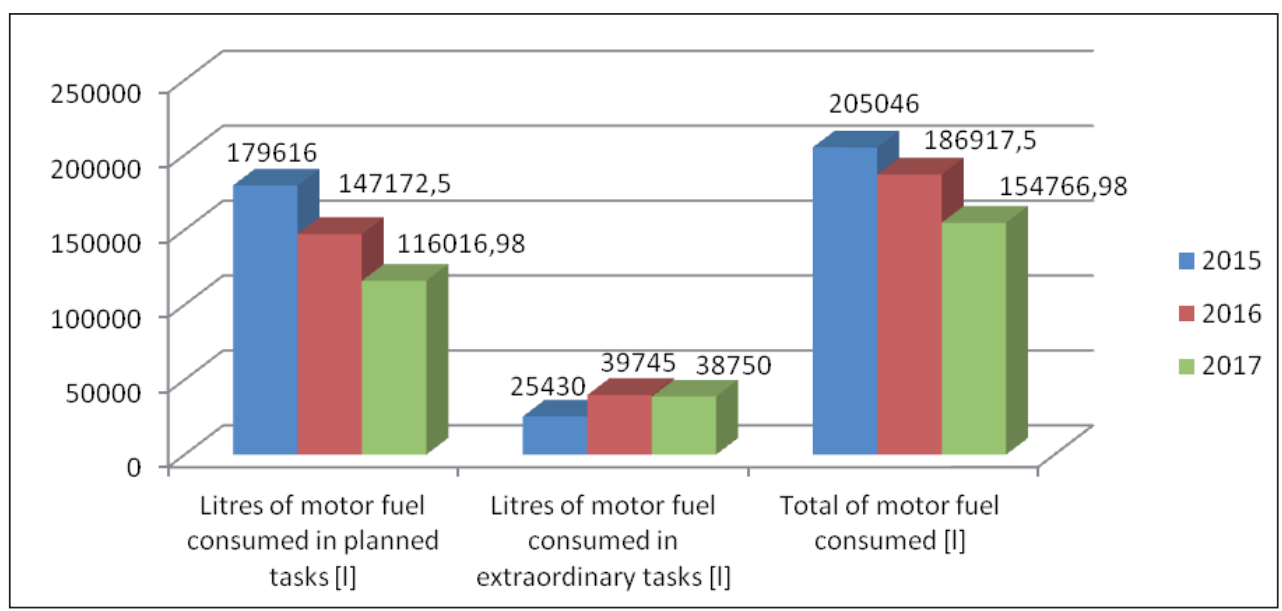

Figure 3 Comparison of motor fuel consumed in the period of time from 2015 to 2017 Source: Author, adapted from $[18,19,20]$

An example of activities performed by CGRC forces is a search and rescue (SAR) operation, carried out on 22 March 2018, when a person fell off a sailing boat in the waters of the Vis channel. The CGRC ship, BŠ-72 Andrija Mohorovičić, while performing a task of following a foreign war ship in direction of the Navy Base Lora, was the first ship that around 1950 hours received an automatically sent distress message from the sailing boat. BŠ-72 was the first to confirm the receipt of the distress message and, in line with standard operating procedures in case of a SAR operation, it notified Split Radio (radio service working 24/7/365).

A duty officer in the MRCC in Rijeka designated the ship BŠ-72 as On Scene Commander (OSC) and informed the ODOCGRC thereof. On the same day a Pilatus PC-9 was included to carry out aerial search in the searching area.

Figure two shows a comparison of nautical miles sailed during all the tasks, both planned and extraordinary ones, completed by the CGRC from 2015 to 2017, within the framework of the Central Coordinating Committee for
Supervision and Protection of the Maritime Rights and Interests of the RC.

An example of activities of CGRC forces performed in international tasks is participation of BŠ-72 Andrija Mohorovičić in a EU's joint humanitarian maritime operation "JO EPN TRITON 2015". In course of the operation "TRITON", BŠ-72 took part in 12 search and rescue operations at sea in which 2,516 people were saved (551 children, 448 women and 1577 men) [14].

Figure three shows a comparison of motor fuel consumed during all the tasks, both planned and extraordinary ones, completed by the CGRC from 2015 to 2017, within the framework of the Central Coordinating Committee for Supervision and Protection of the Maritime Rights and Interests of the RC.

According to the analyses of the completed activities in the last three years, it is possible to conclude that the CGRC has an active role in all the mentioned authorisations and activities it has been carrying out at sea. 


\section{Conclusion}

On the basis of the analysis of the data collected in the period from 2015 to 2017, a significant increase of total CGRC activities, displayed in Table 3, is visible. Considering the displayed, for the purpose of maintaining the achieved level of maritime safety at sea, new investments in equipment and in human resource are of utmost importance in order to modernise and increase efficiency thereof.

The CGRC functional activities are currently mostly reflected in marine fisheries inspections where authorised personnel, after completing the professional training and after being authorised by the Minister, of Agriculture, carry out the tasks of marine fisheries inspection independently, and in this way they perform the job of a marine fisheries inspector. An additional goal is to enable, as soon as possible, authorised personnel of the CGRC to perform navigation safety inspection independently, so as to enhance the protection of passengers, crew, resources and marine environment in the eastern part of the Adriatic Sea, hence, a considerable effort has been invested to provide additional education and training for authorised personnel of the CGRC.

The CGRC has to be capable of providing support to all state administration bodies and other civilian institutions with its naval and attached air forces in order to implement safety of maritime traffic in the Adriatic Sea. This efficiency will only be achieved provided that all the elements of the CGRC are modernised and that its personnel receive constant professional training, which is a matter of great attention.

As a result of joint activities by the Ministry of Defence of the RC, Ministry of the Interior, Ministry of Sea, Transport and Infrastructure and in cooperation with the University of Split, starting from academic year 2018/2019, a new study programme, Naval Studies, is introduced. The Naval Studies programme is an integrated 5-year undergraduate and graduate University study programme intended to educate future maritime officers of the Ministry of Defence, Ministry of the Interior and Ministry of Sea, Transport and Infrastructure.

The aim of this study programme is to achieve uniform education of maritime officers for all state institutions performing in the area of safety at sea, and synergic performance of all the involved parties should protect and preserve interests of the $\mathrm{RC}$ in the area of the Adriatic Sea since it is the most important economic resource of the RC [16].

Despite the improvements made in the last several years in certain areas related to the CGRC, material resources and equipment that the CGRC has at its disposal are partly insufficient. Of course, the most important and most expensive items are ships of general and special purpose.

The security situation on the eastern Adriatic requires also the procurement of fast interceptor boats which are of utmost importance in situations requiring an urgent reaction of the CGRC.

The lack of devices for preventing pollution of the sea (for example, floating security barriers, skimmer pumps for collecting oil from water surfaces, mobile submers- ible turbine pumps for collecting oily waters, etc.) should also be stressed. All of the above-mentioned reduces and obstructs exchange of services among all state administration bodies and civilian services in their mutual activities on the eastern Adriatic.

In line with the Croatian Armed Forces Long-Term Development Plan from 2015 to 2024, the CGRC will develop capabilities of supervising and protecting the maritime rights and interests of the RC through the project of equipping with a series of coastal patrol ships (the first ship from this series was delivered on 7 December 2018), by modernising the existing Enhanced Peregrine coastal surveillance radar system for the purpose of increasing coverage of unsurveyed waters and instant noticing of visually small and very fast vessels at the external borders of the EFPZ (978 $\mathrm{km}$ of the external border), and by fitting the ship SB-73 Faust Vrančić with devices necessary for carrying out ecological operations in case of sudden pollution [21].

In line with the Decision on the Extension of the Jurisdiction of the Republic of Croatia in the. Adriatic Sea of 2008, the RC today does not have jurisdiction over EU Member States' vessels, so that sea pollution from EU Member States' vessels cannot be controlled. By establishing the EFPZ in relation to all countries (including the EU Member States), the marine environment in the EFPZ would be protected in a more efficient way, and it is very likely that this would also increase the engagement of the CGRC in completion of its tasks.

In order to increase the efficiency and optimal use of all of the functional capabilities of the CGRC when carrying out its basic tasks, it is necessary to point out the need of relocating a part of the CGRC naval forces so as the increase the reaction speed, cut down the expenses, prevent all illegal activities at sea, make SAR operations more efficient, increase the navigation safety, improve tracking of navigation of foreign merchant, fishing, war and scientific-research ships in the area under the maritime jurisdiction of the RC.

The mentioned improvements will, for sure, lead to better managing of the overall maritime traffic, i.e. to the overall enhancement of efficiency and operability of the CGRC in surveillance and protection of maritime rights and interests of the RC. In line with the obtained results of the research, it will be possible to recommend a further relocation of a part of the CGRC forces.

Finally, it is necessary to complete the entering of the CGRC ships in the Register of Public Ships of the RC, and allow all the embarked people on the $\mathrm{CN}$ ships to regulate their seagoing service.

\section{References}

[1] The Government of the Republic of Croatia, REGULATION ON ORGANISATION AND MANNER OF WORK OF THE COORDINATING COMMITTEE, EXPERT BODY AND REGIONAL UNITS FOR COORDINATION OF BODIES IN CHARGE OF SUPERVISION AND PROTECTION OF THE MARITIME RIGHTS AND INTERESTS OF THE REPUBLIC OF CROATIA, Official Gazette, Zagreb, No. 77/08., available at: https://narodne- 
novine.nn.hr/clanci/sluzbeni/2008_07_77_2520.html, 2008., (accessed on 3 March. 2018)

[2] The Croatian Parliament, DECISION ON THE EXTENSION OF THE JURISDICTION OF THE REPUBLIC OF CROATIA IN THE. ADRIATIC SEA,, Official Gazette, Zagreb, No. 157/03., available at:https://narodne-novine.nn.hr/clanci/sluzbeni/2003_10_157_2250.html, 2003., (accessed on 1 March. 2018)

[3] The Croatian Parliament, DECISION ON AMENDING THE DECISION ON THE EXTENSION OF THE JURISDICTION OF THE REPUBLIC OF CROATIA IN THE. ADRIATIC SEA, Official Gazette, Zagreb, No. 31/08., available at: https://narodnenovine.nn.hr/clanci/sluzbeni/2008_03_31_998.html, 2008., (accessed on 2 March. 2018)

[4] Act on the Coast Guard of the Republic of Croatia, Official Gazette, Zagreb, No. 109/07., available at:https://www. morh.hr/images/stories/morh_2014/pdf/dpr_osrh_201524_25112014.pdf, 2007., (accessed on 23 March. 2018.)

[5] Amižić Jelovčić, P., Primorac, Ž., Mandić, N.: Obalna straža Republike Hrvatske - pravna vrela, Naše more: znanstveni časopis za more i pomorstvo, 59(5-6), pp. 266-278, 2012.

[6] Barić Punda, V., Juras, D., Kardum, I.: Obalna straža Republike Hrvatske - pravni okvir, mišljenja znanstvenika, praksa, PPP god. 56, 171, pp. 35-60, 2017.

[7] Central Coordinating Committee for Supervision and Protection of the Maritime Rights and Interests of the Republic of Croatia, Annual report on the implementation of determined polices, plans and regulations in relation to supervision and protection of the maritime rights and interests of the Republic of Croatia for the year 2015, available at:https://vlada.gov.hr/ UserDocsImages//Sjednice/2017/10\%20listopad/62\%20 sjednica\%20Vlade $\% 20$ Republike\%20Hrvatske//62\%20 -\%2014.pdf, 2017., (accessed on 23 March. 2018.)

[8] The Armed Forces of the Republic of Croatia, the COAST GUARD OF THE RC, available at: https://www.osrh. hr/\#rubData/HTML/HR/O NAMA/HRM/20181017_Obalna_straža_RH/Obalna_straža_RH_HR.htm, 2018., (accessed on 7 March. 2018)

[9] Decision of the Government of the Republic of Croatia of 27 August 2004, class: 022-03/04-02/33, No.: 5030109/1., available at: https://www.morh.hr/images/stories/ morh_2014/pdf/dpr_osrh_2015-24_25112014.pdf, 2004., (accessed on 23 March. 2018.)

[10] Government of the Republic of Croatia, Annual report on Defence for the year 2017, available at: https://vlada. gov.hr/UserDocsImages //Sjednice/2018/04\%20travnja/333990\%20sjednica\%20VRH//90\%20-\%204.pdf, 2018., (accessed on 23 April. 2018.)

[11] Hrvatski vojnik, HRM na sjevernom Jadranu, No. 518/17., available at: https://hrvatski-vojnik.hr/hrm-na-sjevernomjadranu/, 2017., (accessed on 10 March. 2018)
[12] Komadina P., Nekić, D., Ostović Lj.: Doprinos Obalne straže u optimiziranju sustava za nadzor morskog ribarstva u zaštićenome ekološko-ribolovnom pojasu, Naše more: znanstveni časopis za more i pomorstvo, 59(5-6), pp. 308-317, 2012.

[13] Korda, Z., Krvna slika hrvatskog turizma: Što zapravo stoji iza rekordnih brojki?, available at:https://www.tportal.hr/ biznis/clanak/krvna-slika-hrvatskog-turizma-20170802, 2017., (accessed on 19 March. 2018.)

[14] Mihanović L., Sučević S., Bičanić Z.: Contribution of Croatian navy to the European union security through participation in operation "TRITON", Book of Proceedings - 7th International Maritime Science Conference, Faculty of maritime studies Split, Split, pp. 200-212, 2017.

[15] Ministry of Defence of the Republic of Croatia, 93 ${ }^{\text {rd }}$ Air Force Base, available at: https://www.morh.hr/hr/25-obljetnicahrz-i-pzo/ustrojbene-cjeline-hrz-i-pzo/93-zrakoplovna-baza.html (accessed on 24 March. 2018)

[16] Ministry of Defence of the Republic of Croatia, UNDERGRADUATE AND GRADUATE UNIVERSITY STUDY PROGRAMME OF THE NAVAL STUDIES , available at:https://www.morh.hr/hr/hrvatsko-vojno-uciliste/2013-11-11-12-42-15/vojno-pomorstvo.html, 2018., (accessed on 30 March. 2018)

[17] Republic of Croatia, Ministry of Public Administration, Što predstavlja Schengenski prostor?, available at:https:// uprava.gov.hr/sto-predstavlja-schengenski-prostor-14047/14047 (accessed on 18 March.2018.)

[18] Republic of Croatia, Central Coordinating Committee for Supervision and Protection of the Maritime Rights and Interests of the RC.: Annual report on the implementation of determined polices, plans and regulations in relation to supervision and protection of the maritime rights and interests of the Republic of Croatia for the year 2015., 2016.

[19] Republic of Croatia, Central Coordinating Committee for Supervision and Protection of the Maritime Rights and Interests of the RC.: Annual report on the implementation of determined police, plans and regulations in relation to supervision and protection of the maritime rights and interests of the Republic of Croatia for the year 2016., 2017.

[20] Republic of Croatia, Central Coordinating Committee for Supervision and Protection of the Maritime Rights and Interests of the RC.: Annual report on the implementation of determined polices, plans and regulations in relation to supervision and protection of the maritime rights and interests of the Republic of Croatia for the year 2017., 2018.

[21] The Croatian Armed Forces Long-Term Development Plan from 2015 to 2024, Official Gazette, Zagreb, No.151/14., available at: https://www.morh.hr/images/stories/morh_ 2014/pdf/dpr_osrh_2015-24_25112014.pdf, 2014., (accessed on 23 March. 2018) 